\title{
Pengaruh Penambahan Dedak Padi Halus (Bekatul) dalam Ransum Terhadap Pertambahan Bobot Badan Ayam Broiler Periode Finisher
}

\section{Effect of Addition of Fine Rice Bran (Bran) Rations Toward Agency Added Weight Broiler Chickens Period Finisher}

\author{
Inggal Purnomo ${ }^{1}$, Drh. Dyah Wahyuning Aspirati, S.Pt ${ }^{2}$, Ir. Mufid Dahlan, M.MA ${ }^{3}$ \\ ${ }^{1}$ Mahasiswa Fakultas Peternakan \\ ${ }^{2}$ Dosen Pembimbing Utama \\ ${ }^{3}$ Dosen Pembimbing Pendamping \\ Program Studi Peternakan \\ Fakultas Peternakan, Universitas Islam Lamongan (UNISLA)
}

\section{RINGKASAN}

Penelitian tentang pengaruh tingkat penambahan dedak padi halus dalam ransum terhadap pertambahan bobot badan ayam broiler periode finisher di laksanakan pada tanggal 28 Mei sampai 20 Juni 2016 di peternakan milik Bapak. Abdul Majid Desa Waru, Kecamatan Mantup, Kabupaten Lamongan. Metode penelitian adalah Rancangan Acak Lengkap dengan empat perlakuan tiga ulangan, adapun 3 perlakuan dengan di tambah dedak padi halus (bekatul) $\mathrm{P}_{0}=0 \% \mathrm{P}_{1}=5 \% \mathrm{P}_{2}=10 \% \mathrm{P}_{3}=15 \%$. Penelitian yang diamati ini adalah konsumsi pakan. Pertambahan bobot badan dan konversi ransum, Dari hasil penelitian yang diperoleh rata-rata konsumsi pakan pada perlakuan $\mathrm{P}_{0}=3231$ (gram), tidak berbeda nyata terhadap perlakuan $\mathrm{P}_{1}=3232$ (gram), $\mathrm{P}_{2}=3250$ (gram) dan $\mathrm{P}_{3}=3243$ (gram), Rataan pertumbuhan bobot badan selama penelitian pada perlakuan $\mathrm{P}_{0}=1524$ (gram), tidak berbeda nyata dengan perlakuan $\mathrm{P}_{1}$ $=1528$ (gram), namun berbeda sangat nyata terhadap perlakuan $P_{2}=1601$ (gram) dan $P_{3}=1572$ (gram). Rataan konversi ransum selama penelitian pada perlakuan $\mathrm{P}_{0}=2.11$ (gram) berpengaruh tidak nyata terhadap perlakuan $\mathrm{P}_{1}=2.11$ (gram), $\mathrm{P}_{2}=2.02$ (gram) dan $\mathrm{P}_{3}=2.06$ (gram). Untuk mendapatkan biaya termurah, disarankan menambahkan dedak padi halus (bekatul) sebesar 15 persen dalam pakan jadi agar dapat mengurangi biaya pakan dalam pemeliharan ayam broiler priode finisher.

\begin{abstract}
Research on the influence of the addition of refined rice bran in the ration on body weight gain of broiler finisher period carried on 28 May to 20 June 2016 at the farm owned by Mr. Abdul Majid Waru, District Mantup, Lamongan. The research method was completely randomized design with three replications four treatments, while the 3 treatments with the added refined rice bran (bran) $\mathrm{P} 0=0 \% \mathrm{P} 1$ $=5 \% \quad \mathrm{P} 2=10 \% \quad \mathrm{P} 3=15 \%$. The study observed are feed consumption. Body weight gain and feed conversion, From the research results obtained average feed consumption in treatment $\mathrm{P} 0=3231(\mathrm{~g})$, not significantly different to the treatment P1 $=3232(\mathrm{~g}), \mathrm{P} 2=3250(\mathrm{~g})$ and P3 $=3243(\mathrm{~g})$ the average of the growth of body weight during the study in treatment $\mathrm{P} 0=1524(\mathrm{~g})$, not significantly different from the treatment P1 $=1528(\mathrm{~g})$, but highly significant to the treatments $\mathrm{P} 2=1601(\mathrm{~g})$ and $\mathrm{P} 3=1572(\mathrm{~g})$, Mean feed conversion during the study in treatment $\mathrm{P} 0=2: 11(\mathrm{~g})$ effect no significant effect on the treatment $\mathrm{P} 1=2: 11(\mathrm{~g}), \mathrm{P} 2=2.02(\mathrm{~g})$ and $\mathrm{P} 3=2.06(\mathrm{~g})$. To get the cheapest costs, it is advisable to add a delicate rice bran (bran) by 15 percent in the feed so in order to reduce the cost of feed in chicken broiler period finisher maintenance.

Key Words : Bran, Chicken broiler, Body weights

\section{PENDAHULUAN}

Ayam broiler merupakan ternak unggas yang dapat menghasilkan daging dalam waktu yang singkat serta dapat mengkonsumsi makanan menjadi daging secara efisien. Salah satu faktor yang menentukan efisien tidaknya

produksi ternak adalah jumlah ransum yang dikonsumsi untuk memproduksi satu kilogram berat badan, semakin kecil rasionya berarti semakin efisien produksi ternak tersebut, Ayam broiler adalah ayam yang sengaja dibibitkan dan dikembangkan untuk menghasilkan daging yang
\end{abstract}


cepat dibandingkan dengan ternak unggas lainnya (Fajri, 2012).

Keberhasilan usaha peternakan ayam ditentukan tiga faktor penting yaitu bibit pakan dan manajemen banyak peternak merasakan biaya pakan merupakan beban berat karena sering terjadi fluktuasi harga pakan yang cenderung naik kenaikan harga pakan disebabkan oleh kenaikan harga bahan pakan pokok seperti jagung, bungkil kedelai dan tepung ikan (Murtidjo, 2005).

Dilihat dari segi keuntungan maka peternak ayam dalam posisi yang lemah melihat kondisi demikian banyak peternak mencari alternatif dengan cara mengganti atau menambahkan bahan yang lebih murah dan mudah diperoleh dan bergizi tinggi tanpa mengurangi mutu produk pada pakan jadi,

Pakan jadi yang dibuat oleh pabrik pakan ternak diproduksi tidak untuk satu daerah tertentu, tetapi dibuat secara umum untuk semua jenis daerah dengan memperhatikan standart kebutuhan zat - zat pakan tertentu jika diberikan pada ternak pada daerah yang tertentu, sehingga salah satu alternatif yang diberikan oleh peternak untuk memenuhi kekurangan zat pakan tersebut adalah dengan menambahkan dalam pakan jadi tersebut dengan bahan pakan yang lain yang kaya zat yang dibutuhkan.

Dedak padi halus merupakan hasil sampingan dari proses penggilingan padi, dapat digunakan sebagai bahan penyusun ransum unggas karena mempunyai kadungan zat - zat pakan cukup tinggi serta tidak bersaing dengan konsumsi manusia, realita dedak padi halus telah banyak digunakan oleh peternak sebagai bahan penyusun ransum ayam terutama untuk ayam pedaging (broiler).

Penggunaan dedak padi halus bagi pakan ternak terutama unggas rata-rata berkisar 10-20 persen porsinya. Hal ini karena dedak padi mempunyai banyak keunggulan dibandingkan bahan baku lainya diantara keunggulan dedak padi halus adalah kandungan energinya yang bisa mencapai $2980 \mathrm{kcal} / \mathrm{kg}$ ( NRC, 1994 ) namun nilai ini bukan harga mati karena jumlah energi yang bisa dihasilkan dari dedak padi tergantung dari jumlah serat kasar dan kualitas lemak yang ada didalamya, dedak padi halus merupakan bahan baku ternak dan ikan yang populer digunakan di indonesia dan di beberapa negara.

Oleh karena itu penulis tertarik untuk melakukan penelitian penambahan dedak padi halus untuk penelitian dengan judul "Pengaruh Penambahan Dedak Padi Halus (Bekatul) Dalam Ransum Terhadap Pertambahan Bobot Badan Ayam Broiler Periode Finiser.

\section{METODE PENELITIAN}

Metode penelitian adalah percobaan menggunakan pola rancangan acak lengkap ( RAL ) dengan empat perlakuan tiga ulangan terdiri dari 12 petak tiap petak di isi 5 ekor ayam.

Perlakuan yang diberikan adalah :

Perlakuan I : Pakan jadi $100 \%$ tanpa penambahan dedak padi halus sebagai control $\left(\mathrm{P}_{\mathrm{O}}\right)$.

Perlakuan II : Pakan jadi 95\% ditambah 5\% dedak padi halus $\left(\mathrm{P}_{1}\right)$.

Perlakuan III : Pakan jadi 90\% ditambah 10\% dedak padi halus $\left(\mathrm{P}_{2}\right)$.

Perlakuan IV: Pakan jadi $85 \%$ ditambah $15 \%$ dedak padi halus $\left(\mathrm{P}_{3}\right)$.

\section{VARIABEL PENGAMATAN}

Variabel yang diukur dalam penelitian ini adalah : PBB : Pertambahan Bobot Badan Ayam Broiler fase finisher

\section{Rumus Pertambahan Bobot Badan}

$$
P B B=\frac{W_{2}-W_{1}}{t_{2}-t_{1}}
$$

Keterangan: $t_{1}=$ Waktu awal pengamatan (minggu)

$\mathrm{t}_{2}=$ Waktu akhir pengamatan (minggu)

$\mathrm{W}_{1}=$ Bobot badan awal $(\mathrm{kg})$

$\mathrm{W}_{2}=$ Bobot badan akhir $(\mathrm{kg})$

\section{ANALISIS DATA}

Data konsumsi pakan dan pertambahan bobot badan dianalisa dengan menggunakan analisis ragam ( Yitnosumarto, 1989)

Model matematik dikemukakan sebagai berikut :

$$
\mathrm{Y}_{\mathrm{iJ}}=\pi+\tau_{1}+€_{\mathrm{iJ}}
$$

Dimana : 
$\mathrm{Y}_{\mathrm{iJ}}=$ nilai pengamatan dalam perlakuan ke I ulangan ke $\mathrm{j}$.

$$
\begin{aligned}
& \Pi=\text { nilai tengah umum } \\
& \tau_{1}=\text { pengaruh perlakuan ke } \mathrm{i} \text {. } \\
& €_{\mathrm{iJ}}=\text { kesalahan percobaan pada } \\
& \text { perlakuan ke I ulangan ke j. }
\end{aligned}
$$

\section{HASIL DAN PEMBAHASAN}

\section{Energi Dalam Ransum}

Data dari hasil laboratorium kandungan proksimat dari tiap masing - masing perlakuan dapat pada tabel 3, Hasil laboratorium kedokteran hewan universitas airlangga.

Tabel 3 : Hasil Laboratorium Kedokteran Hewan Universitas Airlangga.

\begin{tabular}{|c|c|c|c|c|c|}
\hline \multirow{2}{*}{$\begin{array}{c}\mathrm{N} \\
\mathrm{o}\end{array}$} & \multirow{2}{*}{$\mathrm{KS}$} & \multicolumn{5}{|c|}{ Hasil Analisis (\%) } \\
\cline { 3 - 6 } & & $\mathrm{PK}$ & $\mathrm{LK}$ & $\mathrm{SK}$ & $\begin{array}{c}\text { Energi } \\
\text { Metabolisme } \\
\text { (kkal/kg) }\end{array}$ \\
\hline 1 & $\begin{array}{c}\mathrm{Be} \\
\mathrm{kat} \\
\mathrm{ul}\end{array}$ & 10,4607 & $\begin{array}{c}8,460 \\
7\end{array}$ & $\begin{array}{c}7,532 \\
0\end{array}$ & 3086,4782 \\
\hline 2 & $\mathrm{P}_{0}$ & 19,3138 & 4,699 & 5,488 & 2945,8484 \\
& & & 7 & 3 & \\
\hline 3 & $\mathrm{P}_{1}$ & 19,7716 & $\begin{array}{c}4,956 \\
8\end{array}$ & $\begin{array}{c}6,350 \\
7\end{array}$ & 2955,3763 \\
\hline 4 & $\mathrm{P}_{2}$ & 19,7337 & $\begin{array}{c}4,951 \\
4\end{array}$ & $\begin{array}{c}6,007 \\
1\end{array}$ & 2965,8860 \\
\hline 5 & $\mathrm{P}_{3}$ & 19,4721 & 6,220 & 6,976 & 2965,9451 \\
\hline
\end{tabular}

Sumber : unair (2016)

Dari hasi laboratorium penambahan dedak padi halus (bekatul) dalam pakan jadi finisher dengan kandungan energy metabolis dedak padi halus (bekatul) sebesar 3086,4782 $\mathrm{kkal} / \mathrm{kg}$, maka penambahan sebesar 5 persen $\left(\mathrm{P}_{1}\right.$ ) energy dalam ransum menjadi 2955,3763 $\mathrm{kkal} / \mathrm{kg}$ ransum dengan penambahan sebesar 10 persen $\left(\mathrm{P}_{2}\right)$ menjadi 2965,8860 $\mathrm{kkal} / \mathrm{kg}$, dengan penambahan sebesar 15 persen $\left(\mathrm{P}_{3}\right)$ menjadi $2965,9451 \mathrm{kkal} / \mathrm{kg}$.
Tabel 4 : Pertambahan Energi Metabolisme (kkal/kg) Pada Tiap Perlakuan.

\begin{tabular}{|c|c|c|c|}
\hline \multicolumn{2}{|c|}{$\begin{array}{c}\text { Perlakuan } \\
\text { Energi } \\
\text { Metabolisme } \\
(\mathrm{kkal} / \mathrm{kg})\end{array}$} & $\begin{array}{c}\mathrm{P}_{0} \text { Energi } \\
\text { Metabolisme } \\
(\mathrm{kkal} / \mathrm{kg})\end{array}$ & $\begin{array}{c}\text { Pertambahan } \\
\text { Energi } \\
\text { Metabolisme } \\
(\mathrm{kkal} / \mathrm{kg})\end{array}$ \\
\hline $\mathrm{P}_{1}$ & 2955,3763 & 2945,8484 & 9,5279 \\
\hline $\mathrm{P}_{2}$ & 2965,8860 & 2945,8484 & 20,0376 \\
\hline $\mathrm{P}_{3}$ & 2965,9451 & 2945,8484 & 20,0967 \\
\hline
\end{tabular}

Sumber : Data Primer Diolah (2016)

Dengan penambahan dedak padi halus (bekatul) dalam pakan jadi finisher dengan kandungan energy metabolis dedak padi halus (bekatul) sebesar $3086.4782 \mathrm{kkal} / \mathrm{kg}$, maka penambahan sebesar 5 persen $\left(\mathrm{P}_{1}\right)$ energy dalam ransum akan meningkat sebesar 9.5279 $\mathrm{kkal} / \mathrm{kg}$ ransum dengan penambahan sebesar 10 persen $\left(\mathrm{P}_{2}\right)$ meningkat sebesar $20.0376 \mathrm{kkal} / \mathrm{kg}$, dengan penambahan sebesar 15 persen $\left(\mathrm{P}_{3}\right)$ meningkat sebesar $20.0967 \mathrm{kkal} / \mathrm{kg}$, menurut Anggorodi ( 1985 ) adalah 2800 - $3400 \mathrm{kkal} / \mathrm{kg}$, maka dengan penambahan dedak padi halus (bekatul) sebesar 5, 10 dan 15 persen diperkirakan telah mencukupi kebutuhan energy.

\section{Konsumsi Pakan}

Dari hasil penelitian rata - rata konsumsi ayam per ekor dari masing - masing perlakuan dan ulangan dapat pada Tabel 5 .

Tabel 5 : Rata - Rata Konsumsi Pakan Selama

\begin{tabular}{|c|c|c|c|c|c|}
\hline \multirow{2}{*}{ Perlakuan } & \multicolumn{3}{|c|}{ Ulangan } & \multirow{2}{*}{ Jumlah } & \multirow{2}{*}{$\begin{array}{l}\text { Rata- } \\
\text { Rata }\end{array}$} \\
\hline & $\mathrm{U}_{1}$ & $\mathrm{U}_{2}$ & $\mathrm{U}_{3}$ & & \\
\hline $\mathrm{P}_{0}$ & 3222 & 3248 & 3223 & 9693 & 3231 \\
\hline $\mathrm{P}_{1}$ & 3231 & 3234 & 3231 & 9696 & 3232 \\
\hline $\mathrm{P}_{2}$ & 3241 & 3253 & 3256 & 9750 & 3250 \\
\hline $\mathrm{P}_{3}$ & 3242 & 3245 & 3243 & 9730 & 3243 \\
\hline \multicolumn{4}{|c|}{ Total } & 38869 & \\
\hline
\end{tabular}
Penelitian Per Ekor Pada Masing - Masing Perlakuan dan Ulangan Umur $22-42$ (hari/gram)

Sumber : Data Primer Diolah (2016)

Dari hasil penelitian di atas pada Tabel 5 , ayam yang diberi pakan dengan ransum ditambah dedak padi halus (bekatul) sebesar 10 persen, menunjukan konsumsi pakan yang tertinggi di bandigkan dengan ransum control, 
ransum yang ditambah dengan dedak padi halus (bekatul) sebesar 15 dan 10 persen, pada kondisi ini ayam dalam kondisi pertumbuhan yang optimum dan menghasilkan pertambahan bobot yang maksimum. disamping itu juga pakan lebih banyak dikonsumsi untuk memenuhi kebutuhan energy dalam mempertahankan kondisi tubuh dari temperature lingkungan, hal ini sesuai dengan pendapat Murtidjo (2005 ), bahwa ayam pedaging cenderung meningkatkan jumlah konsumsi pakan bila kadungan dalam ransum rendah.

Tabel 6, Hasil Sidik Ragam Konsumsi Pakan

\begin{tabular}{|c|c|c|c|c|c|c|}
\hline \multirow{2}{*}{$\begin{array}{c}\text { Sumber } \\
\text { Keragaman }\end{array}$} & \multirow[t]{2}{*}{ DB } & \multirow[t]{2}{*}{ JK } & \multirow[t]{2}{*}{ KT } & \multirow{2}{*}{$\begin{array}{c}\mathrm{F} \\
\text { hitun } \\
\mathrm{g}\end{array}$} & \multicolumn{2}{|c|}{ F table } \\
\hline & & & & & $5 \%$ & $1 \%$ \\
\hline Perlakuan & 3 & 758 & 252 & $3,30^{\mathrm{hi}}$ & 4,07 & 7,59 \\
\hline Galat & 8 & 571 & 71.4 & $\mathrm{t}$ & & \\
\hline Total & 11 & $\begin{array}{c}132 \\
9\end{array}$ & & & & \\
\hline
\end{tabular}

Sumber : Data Primer Diolah (2016)

Dari hasil sidik ragam di atas pada Tabel 6, menunjukan berbagai tingkat penambahan dedak padi halus (bekatul) $\mathrm{P}_{0}$ tidak berbeda bengan $\mathrm{P}_{1}, \mathrm{P}_{2}$, dan $\mathrm{P}_{3}$ secara statistik tidak memberikan pengaruh yang nyata terhadap konsumsi pakan karana $\mathrm{F}$ hitung lebih kecil dari F tabel 5\%.

\section{Pertambahan Bobot Badan}

Data rata - rata pertambahan bobot ayam per ekor dari masing - masing perlakuan dan ulangan dapat dilihat pada tabel 7.

Tabel 7 : Rata - Rata Pertambahan Bobot Badan Pada Masing - Masing Perlakuan dan Ulangan Umur 22 - 42 Hari (Gram/Ekor).

\begin{tabular}{|c|c|c|c|c|c|}
\hline \multirow[t]{2}{*}{ Perlakuan } & \multicolumn{3}{|c|}{ Ulangan } & \multirow[t]{2}{*}{ Jumlah } & \multirow{2}{*}{$\begin{array}{l}\text { Rata- } \\
\text { Rata }\end{array}$} \\
\hline & $\mathrm{U}_{1}$ & $\mathrm{U}_{2}$ & $\mathrm{U}_{3}$ & & \\
\hline $\mathrm{P}_{0}$ & 1485 & 1502 & 1587 & 4574 & 1524 \\
\hline $\mathrm{P}_{1}$ & 1495 & 1491 & 1598 & 4584 & 1528 \\
\hline $\mathrm{P}_{2}$ & 1600 & 1584 & 1619 & 4803 & 1601 \\
\hline $\mathrm{P}_{3}$ & 1522 & 1600 & 1594 & 4716 & 1572 \\
\hline \multicolumn{4}{|c|}{ Total } & 18677 & \\
\hline
\end{tabular}

Sumber : Data Primer Diolah (2016)
Seperti pada Tabel 7 di atas pertambahan bobot badan, dengan penambahan dedak padi halus (bekatul) sebesar 10 persen menunjukan pertambahan bobot badan yang tertinggi, Pada kondisi ini energy yang dibutuhkan oleh ayam tercukupi dan dalam kondisi optimum sehingga akan menghasilkann pertambahan bobot yang maksimum.

Pada ransum kontrol tanpa penambahan dedak padi halus (bekatul) dalam ransum dengan penambahan dedak padi halus (bekatul) sebesar 5 persen, diasumsikan kebutuhan energy untuk mempertahankan kondisi tubuhnya terhadap temperature lingkungan, namun karena kapasitas tempolok terbatas ayam tidak dapat mengkonsumsi pakan lebih banyak lagi untuk memperoleh energy, Kurangnya energy tersebut akan mengganggu pertumbuhan dan menghasilkan pertambahan bobot badan yang rendah, hal ini sesuai dengan pendapat Anggorodi ( 1985 ), yang menyatakan bahwa ransum yang berenergi rendah akan menghasilkan ayam - ayam yang kurus karena ayam tidak dapat mengkonsumsi cukup energy untuk memperoleh pertumbuhan yang normal dan tidak akan menimbun lemak dalam jumlah yang cukup normal di dalam jaringan tubuhnya.

Tabel 8 : Hasil Sidik Ragam Pertambahan Bobot Badan.

\begin{tabular}{|c|c|c|c|c|c|c|}
\hline $\begin{array}{c}\text { Sumber } \\
\text { Keragaman }\end{array}$ & DB & JK & KT & $\begin{array}{c}\text { F } \\
\text { hitung }\end{array}$ & \multicolumn{2}{|c|}{ F table } \\
\cline { 4 - 7 } & & & & & $5 \%$ & $1 \%$ \\
\hline $\begin{array}{c}\text { Perlakuan } \\
\text { Galat }\end{array}$ & 3 & 12138 & 4046 & $0,68^{\text {hit }}$ & 4,07 & 7,59 \\
\hline Total & 11 & 29851 & 5904 & & & \\
\hline
\end{tabular}

Sumber : Data Primer Diolah (2016)

Dari hasil sidik ragam di atas pada Tabel 8, menunjukan berbagai tingkat penambahan dedak padi halus (bekatul) $\mathrm{P}_{0}$ tidak berbeda bengan $\mathrm{P}_{1}, \mathrm{P}_{2}$, dan $\mathrm{P}_{3}$ secara statistik tidak memberikan pengaruh yang nyata terhadap pertambahan bobot badan karana $\mathrm{F}$ hitung lebih kecil dari $\mathrm{F}$ tabel $5 \%$ dan $1 \%$ 


\section{Konversi Ransum}

Data rata - rata konversi ransum per ekor dari masing - masing perlakuan dan ulangan dapat dilihat pada Tabel 9.

Tabel 9 : Rata - Rata Konversi Ransum Pada Masing - Masing Perlakuan Dan Ulangan Umur 22 - 42 Hari (Gram/Ekor).

\begin{tabular}{|c|c|c|c|c|c|}
\hline \multirow{2}{*}{$\begin{array}{c}\text { Perl } \\
\text { aku } \\
\text { an }\end{array}$} & \multicolumn{3}{|c|}{ Ulangan } & \multirow{2}{*}{$\begin{array}{c}\text { Jumla } \\
\mathrm{h}\end{array}$} & \multirow{2}{*}{$\begin{array}{l}\text { Rata- } \\
\text { Rata }\end{array}$} \\
\hline & $\mathrm{U}_{1}$ & $\mathrm{U}_{2}$ & $\mathrm{U}_{3}$ & & \\
\hline $\mathrm{P}_{0}$ & 2.16 & 2.16 & 2.03 & 6.35 & 2.11 \\
\hline $\mathrm{P}_{1}$ & 2.16 & 2.17 & 2.02 & 6.35 & 2.11 \\
\hline $\mathrm{P}_{2}$ & 2.02 & 2.05 & 2.01 & 6.08 & 2.02 \\
\hline $\mathrm{P}_{3}$ & 2.13 & 2.02 & 2.03 & 6.18 & 2.06 \\
\hline \multicolumn{4}{|c|}{ Total } & 24.96 & \\
\hline
\end{tabular}

Sumber : Data Primer Diolah (2016)

Dari hasil penelitian konversi ransum pada Tabel 9 di atas ini menunjukan $\mathrm{P}_{0}$ tidak berbeda dengan $\mathrm{P}_{1}, \mathrm{P}_{2}$ dan $\mathrm{P}_{3}$. Dengan penambahan dedak padi halus (bekatul) dalam pakan jadi finisher, dalam kondisi ini pada perlakuan $\mathrm{P}_{2}=10 \%$ sebesar (2.02), menunjukan konversi ransum relative lebih rendah dibandingkan dengan konversi ransum kotrol, konversi ransum yang ditambahkan dengan dedak padi halus (bekatul) pada perlakuan $\mathrm{P}_{1}=$ $5 \%$ sebesar (2.11), dan $\mathrm{P}_{3}=15 \%(2,06)$, walaupun secara statistic tidak berbeda nyata disebabkan kandungan energy dalam pakan berkaitan dengan kandungan protein, sedangkan ayam mengkonsumsi pakan untuk memenuhi kebutuhan energinya, kandungan energi dan protein yang terdapat di dalam ransum pada tiap perlakuan disusun hampir sama sehingga menyebabkan pengaruh yang tidak berbeda nyata. Anggorodi ( 1985 ), yang menyatakan tingkatan protein berkaitan dengan kandungan energy ransum, maka kekurangan protein yang ringan akan mengakibatan pertumbuhan menurun, kekurangan yang parah akan mengakibatkann penghentian pertumbuhan dengan segera dan kehilangan pertumbuhan yang menyolok.
Tabel 10 : Hasil Sidik Ragam Konversi Ransum.

\begin{tabular}{|c|c|c|c|c|c|c|}
\hline $\begin{array}{c}\text { Sumber } \\
\text { Keragaman }\end{array}$ & DB & JK & KT & $\begin{array}{c}\text { F } \\
\text { hitung }\end{array}$ & \multicolumn{2}{|c|}{ F table } \\
\cline { 4 - 7 } & & & & & $5 \%$ & $1 \%$ \\
\hline $\begin{array}{c}\text { Perlakuan } \\
\text { Galat }\end{array}$ & 3 & 0.0059 & 0.0059 & $1,40^{\text {hit }}$ & 4,07 & 7,59 \\
\hline Total & 11 & 0.0336 & 0.0042 & & & \\
\hline
\end{tabular}

Sumber : Data Primer Diolah (2016)

Dari hasil sidik ragam di atas pada Tabel 10, menunjukan berbagai tingkat penambahan dedak padi halus (bekatul) $\mathrm{P}_{0}$ tidak berbeda bengan $\mathrm{P}_{1}, \mathrm{P}_{2}$, dan $\mathrm{P}_{3}$ secara statistik tidak memberikan pengaruh yang nyata terhadap konversi ransum karana $\mathrm{F}$ hitung lebih kecil dari F tabel $5 \%$ dan $1 \%$.

\section{Analisa Biaya Pakan}

Data hasil analisa biaya pakan yang di berikan pada masing - masing perlakuan per satu kilo dapat dilihat pada Tabel 11.

Tabel 11. Analisa Biaya Pakan Tiap Perlakuan Per 1 Kilo Pakan.

\begin{tabular}{|c|c|c|c|c|c|}
\hline \multirow{2}{*}{$\begin{array}{c}\text { Perlak } \\
\text { uan }\end{array}$} & \multicolumn{2}{|c|}{ Kebutuha } & \multicolumn{2}{|c|}{ Harga Per Kilo } & \multirow{2}{*}{$\begin{array}{c}\text { Total } \\
\text { Per Kilo }\end{array}$} \\
\hline & $\begin{array}{c}\text { Pakan } \\
\text { Jadi } \\
\text { (gram) }\end{array}$ & $\begin{array}{l}\text { Menir } \\
\text { Jagung } \\
\text { (gram) }\end{array}$ & $\begin{array}{c}\text { Pakan } \\
\text { Jadi } \\
7,500 \\
\mathrm{~kg}\end{array}$ & $\begin{array}{c}\text { Bekatu } \\
1 \\
2,500 \\
\mathrm{~kg}\end{array}$ & \\
\hline P0 & 1000 & - & 7,500 & - & 7,500 \\
\hline P1 & 950 & 50 & 7,125 & 125 & 7,250 \\
\hline P2 & 900 & 100 & 6,750 & 250 & 7,000 \\
\hline P3 & 850 & 150 & 6,375 & 375 & 6,750 \\
\hline
\end{tabular}

Sumber : Data Primer Diolah (2016)

Dari hasil analisa pada Tabel 11 di atas asumsi harga pakan tiap - tiap perlakuan adalah dengan penambahan dedak padi halus (bekatul) sebesar 5 persen $\left(\mathrm{P}_{1}\right)$ diperoleh harga pakan Rp. 7,500 per $\mathrm{kg}$, dengan penambahan dedak padi halus (bekatul) sebesar 10 persen $\left(\mathrm{P}_{2}\right)$ diperoleh harga pakan Rp 7,000 per kg, dengan penambahan dedak padi halus (bekatul) sebesar 15 persen $\left(\mathrm{P}_{3}\right)$ diperoleh harga pakan Rp. 6,750 per kg.

Data hasil analisa biaya pakan selama penelitian pada masing - masing perlakuan per 
ekor ayam umur 22 - 42 hari dapat dilihat pada Tabel 12.

Tabel 12. Analisa Biaya Pakan Selama Penelitian Tiap Perlakuan Per Ekor Ayam Umur 22 - 42 Hari.

\begin{tabular}{|c|c|c|c|}
\hline Perlakuan & $\begin{array}{c}\text { Harga } \\
\text { pakan } \\
\text { per kilo }\end{array}$ & $\begin{array}{c}\text { Konsumsi } \\
\text { Pakan Per } \\
\text { Ekor } \\
\text { (gram) }\end{array}$ & Total \\
\hline P0 & 7,500 & 3231 & 24,232 \\
\hline P1 & 7,250 & 3232 & 23,432 \\
\hline P2 & 7,000 & 3250 & 22,750 \\
\hline P3 & 6,750 & 3243 & 21,890 \\
\hline
\end{tabular}

Sumber : Data Primer Diolah (2016)

Dari hasil analisa biaya pakan tiap perlakuan selama penelitian pada Tabel 12 di atas menunjukan asumsi harga pakan tiap - tiap perlakuan adalah dengan penambahan dedak padi halus (bekatul) sebesar 5 persen $\left(\mathrm{P}_{1}\right)$ diperoleh harga pakan Rp. 23.432 per ekor, dengan penambahan dedak padi halus (bekatul) sebesar 10 persen $\left(\mathrm{P}_{2}\right)$ diperoleh harga pakan Rp. 22.750 per ekor, dengan penambahan dedak padi halus (bekatul) sebesar 15 persen $\left(\mathrm{P}_{3}\right)$ diperoleh harga pakan Rp. 21,890 per ekor. Secara ekonomis penambahan pakan dedak padi halus (bekatul) yang paling baik adalah 15 persen karna menunjukan biaya pakan termura di bandingkan dengan ransum kontrol dan ransum yang ditambah dedak padi halus (bekatul) sebesar 5 persen dan 10 persen.

\section{Kesimpulan}

\section{KESIMPULAN DAN SARAN}

disimpulkan bahwa beberapa tingkat penambahan dedak padi halus (bekatul) dalam pakan jadi finisher tidak memberikan pengaruh yang nyata karna $\mathrm{F}$ hitung lebih kecil dari $\mathrm{F}$ tabel terhadap konsumsi pakan, pertambahan bobot badan dan konversi pakan.

Secara ekonomis penambahan dedak padi halus (bekatul) dalam pakan jadi finisher yang paling baik sebesar 15 persen, karena menunjukan biaya yang termurah, walaupun menunjukan konsumsi pakan yang tinggi juga menunjukan pertambahan bobot badan yang tidak terlalu tinggi.

\section{Saran}

Untuk mendapatkan biaya termurah, di sarankan menambahkan dedak padi halus (bekatul) sebesar 15 persen dalam pakan jadi agar dapat mengurangi biaya pakan dalam pemeliharan ayam broiler.

\section{DAFTAR PUSTAKA}

Anggorodi, R. 1985. Kemajuan Mutakhir Dalam Ilmu Makanan Ternak Unggas. Universitas Indonesia Press. Jakarta.

Fajri. 2012. Pertambahan Berat Badan, Konsumsi dan Konversi Pakan Broiler Yang MendapatRansum Mengandung Berbagai Level Tepung Daun Katuk.Fakultas Peternakan. Universitas Hasanuddin Makasar.

Ichwan. W. 2003. Membuat Pakan Ayam Ras Pedaging. Penyuting Tetti Yulia; Cetak Pertama. Pustaka Agromedia. Jakarta.

Khomari (2005). Pengaruh penambahan menir jagung pada pakan jadi. Skripsi Fakultas Peternakan. Universitas Islam Lamongan

Murtidjo, B, A. 2005. Pedoman Meramu Pakan Unggas. Kanisius. Yogyakarta.

National Research Council.1994.Nutrient Requirements of Poultry $9^{\text {th }}$ Resived Edition. National Academic Press. Washington,DC.

Rasyaf, M. 2004. Beternak Ayam Pedaging.Penebar Swadaya. Jakarta. Dalam Skripsi Fajeri Fakultas Peternakan, Hasanudin Makasar

Suprijatna, Dkk, E,2005. Ilmu Dasar Ternak Unggas. Penebar Swadaya: Jakarta.

Wahyuni, Dkk, 2011. Respon Broiler Terhadap Ransum Pemberian Dedak Padi Fermentasi. Oleh Aspergillus ficuum Kapang J. Ilmu Ternak, Juni 2011, No. 10 Vol. 1. Bandung 26-31

Zulkarnaen (2013). Beternak Ayam Broiler. Jl. Kupang Krajan I no 97D Surabaya. email : dafa_publishing@yahoo.co.id 